\title{
Synthesis and antiviral activity of nonannulated tetrazolylpyrimidines
}

\author{
Vladimir A. Ostrovskii ${ }^{1}$, Gevorg G. Danagulyan ${ }^{2,3}$, Olga M. Nesterova ${ }^{1}$, \\ Yulia N. Pavlyukova ${ }^{1}$, Vladimir V. Tolstyakov ${ }^{1}$, Olga S. Zarubina ${ }^{1}$, \\ Pavel A. Slepukhin ${ }^{4}$, Yana L. Esaulkova ${ }^{5}$, Anna A. Muryleva ${ }^{5}$, \\ Vladimir V. Zarubaev ${ }^{5}$, Rostislav E. Trifonov ${ }^{1}$ \\ ${ }^{1}$ Saint Petersburg State Institute of Technology (Technical University), \\ 26 Moskovsky Ave., Saint Petersburg 190013,Russia; e-mail:va_ostrovskii@mail.ru \\ ${ }^{2}$ Russian-Armenian (Slavonic) University, \\ 123 Hovsep Emin St., Yerevan 0051,Armenia; e-mail: gevorg.danagulyan@rau.am \\ ${ }^{3}$ Technological Center of Organic and Pharmaceutical Chemistry, \\ National Academy of Sciences of the Republic of Armenia, \\ 26 Azatutyan Ave., Yerevan 0014, Armenia; e-mail: gdanag@email.com \\ ${ }^{4}$ Postovsky Institute of Organic Synthesis, Ural Branch of the Russian Academy of Sciences, \\ 22/20 Sofyi Kovalevskoi St., Yekaterinburg 620108, Russia; e-mail: slepukhin@ios.uran.ru \\ ${ }^{5}$ Saint Petersburg Pasteur Research Institute of Epidemiology and Microbiology, \\ 14 Mira St., Saint Petersburg 197101, Russia; e-mail: zarubaev@gmail.com
}<smiles>Cc1cc(C)nc(NNC(=O)Cn2nnc(-c3ccccc3)n2)n1</smiles><smiles>Cc1cc(C)nc(-n2nc(Cn3nnc(-c4ccccc4)n3)cc2O)n1</smiles><smiles>Cc1cc(C)nc(Sc2nnnn2CC(=O)O)n1</smiles>

Nonannulated tetrazolylpyrimidines in the structure of which the heterocyclic fragments are separated by hydrazinocarbonylmethyl, methylpyrazolyl groups or a sulfur atom were synthesized. Some of these compounds showed moderate in vitro activity against H1N1 subtype of influenza A virus. The selectivity index of the anti-influenza action of $\{5$-[(4,6-dimethylpyrimidin-2-yl)sulfanyl]-1H-tetrazol$1-y l\}$ acetic acid, which has very low cytotoxicity, was twice as high as the selectivity index of the reference drug rimantadine.

Keywords: pyrimidines, tetrazoles, biological activity, linkers, properties, structure, synthesis.

The relevance of the development of new antiviral drugs, as a rule, is determined by the presence or absence of prophylactic vaccines against newly emerging infections, as well as the ability of viruses to escape the host immune response and develop drug-resistant strains. ${ }^{1}$ The current situation has sharply exacerbated the problem of the availability of drugs against highly pathogenic variants of the influenza virus and the SARS2 coronavirus, the cause of COVID-19. The solution of this problem is determined by the effectiveness of the search for new drugs for the treatment of influenza and associated infectious diseases. Compounds of various structures are used in the treatment of this viral disease (Fig. 1). In this context, drugs that contain fragments of heterocyclic compounds, azoles and azines, in their active pharmaceutical ingredients (API) are of particular interest.
In 2014, riamilovir (Triazavirin) was registered as a drug for the treatment of influenza in the Russian Federation. ${ }^{2}$ Triazavirin has recently been proven effective in treating the new coronavirus infection and is well tolerated by patients with COVID-19. ${ }^{3}$ Triazavirin API, 7-(methylsulfanyl)3-nitro[1,2,4]triazolo[5,1-c]triazin-4(1H)-one belongs to annulated azoloazines, which indirectly indicates the prospect of searching for new agents for influenza chemotherapy in the ranks of biannulated ("hybrid") heterocyclic compounds based on azoles and azines. Derivatives of tetrazole and pyrimidine are among the most sought after scaffolds in modern medicinal chemistry. ${ }^{4,5}$ In particular, it was shown that some tetrazole derivatives exhibit pronounced activity against rhinoviruses ${ }^{6 a}$ and various strains of influenza A virus. ${ }^{6 \mathrm{~b}}$ In this regard, the synthesis and study of biological activity of binuclear 
<smiles>NC(=O)c1ncn([C@@H]2O[C@H]3COC[C@H]2[C@H]3O)n1</smiles>

Ribavirin<smiles>[R6]O[Na]</smiles>

Remdesivir<smiles>CSc1nc2[nH]nc([N+](=O)[O-])c(=O)n2n1</smiles>

Triazavirin<smiles>O=C(O)CCCC(=O)NCCc1c[nH]cn1</smiles><smiles>CC(NCCl)C12CC3CC(CC(C3)C1)C2</smiles>

Rimantadine

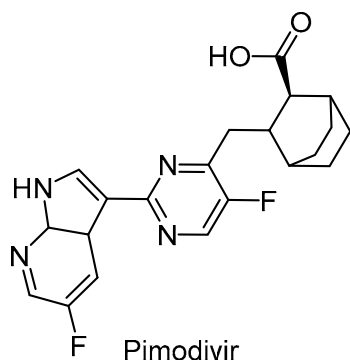

Figure 1. Active pharmaceutical ingredients of drugs used for influenza chemotherapy.

heterocyclic compounds containing both tetrazolyl and pyrimidyl fragments in their structure are of interest. In the case of annulated tetrazolylpyrimidines, the possibility of azidoazomethine-tetrazole isomerism should be considered. ${ }^{7,8}$ For some represantives of this series, the equilibrium can be shifted toward the open-chain azide form with significant cytotoxicity.

In this study, a series of nonannulated tetrazolylpyrimidines was synthesized, and their structure and antiinfluenza activity were investigated as well. Fragments of different nature were chosen as linker groups connecting the tetrazole and pyrimidine heterocycles - methylene, hydrazinylcarbonylmethyl, pyrazolyl groups and a sulfur atom. This set of linkers would allow us to assess the prospects of given structural types in regards to biological activity.

At the first stage of our study, we attempted to synthesize 4,6-dimethyl-2-(5-phenyl-2 $H$-tetrazol-2-yl)pyrimidine (3) by direct hetarylation of the sodium salt of 5-phenyltetrazole (1) by 2-chloro-4,6-dimethylpyrimidine (2). However, it was not possible to isolate the target tetrazolylpyrimidine $\mathbf{3}$ from the reaction mixture. Instead of nonannulated tetrazolylpyrimidine $\mathbf{3}$, a compound was formed the properties of which were identical to those of 5,7-dimethyl-3-phenyl $[1,2,4]$ triazolo[4,3-a]pyrimidine

\section{Scheme 1}<smiles>Cc1cc(C)nc(Cl)n1</smiles><smiles>Cc1cc(C)nc(-n2nnc(-c3ccccc3)n2)n1</smiles>

described earlier. ${ }^{9}$ A possible reason for the discovered phenomenon is the thermolytic recyclization of intermediate 3 accompanied by the elimination of an $\mathrm{N}_{2}$ molecule and the formation of annulated triazolylpyrimidine 4 (Scheme 1).

Considering this experience, we focused our efforts on the synthesis of nonannulated tetrazolylpyrimidines in the structure of which heterocyclic fragments are linked by linker groups such as hydrazinocarbonylmethyl, pyrazolyl, as well as a sulfur atom. To form a linking bridge in the target compounds, we used classical methods such as acylation of the terminal nitrogen atom of the $\mathrm{NHNH}_{2}$ group with carboxylic acid halides, hydrazinolysis of esters, and the substitution of the chlorine atom in the corresponding hetaryls for a sulfur atom by the action of hetarylthiones. ${ }^{10}$ Hydrazides $\mathbf{7 a , b}$ were obtained by acylation of 2-hydrazinylpyridines (5a) or 2-hydrazinyl4,6-dimethylpyrimidine (5b) with 5-phenyltetrazol-2-ylacetic acid chloride (6) (Scheme 2).

1-(4,6-Dimethylpyrimidin-2-yl)-3-[(5-phenyl-2H-tetrazol2-yl)methyl]-1H-pyrazol-5-ol (9) was accessed by hydrazinolysis of ethyl 3-oxo-4-(5-phenyl-2 $H$-tetrazol-2-yl)-

Scheme 2
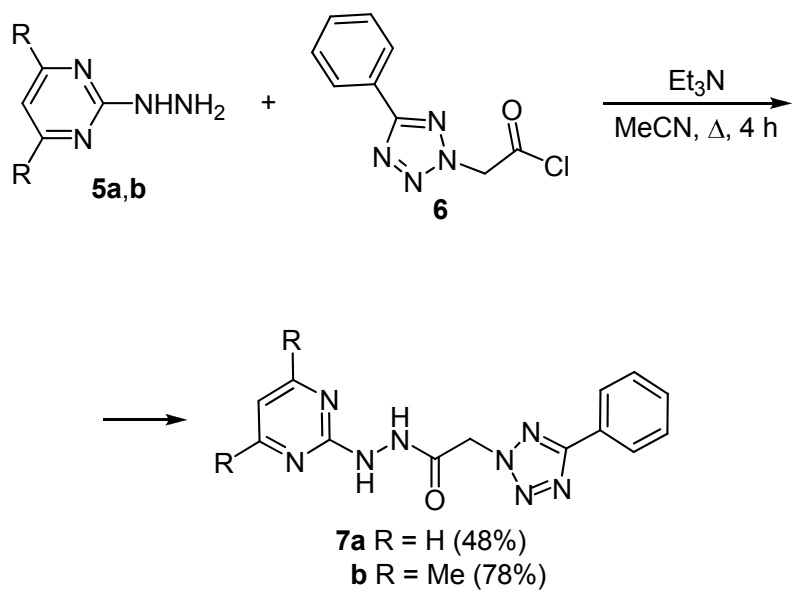
butanoate (8) by 2-hydrazinyl-4,6-dimethylpyrimidine (5b) (Scheme 3). According to X-ray structural analysis data, the pyrazole fragment of compound $\mathbf{9}$ exists in the aromatic form - a hydroxy group is present at position 5. The rendering of the structures of the molecules of compounds $\mathbf{7 b}$ and 9 according to X-ray structural analysis data is shown in Figure 2.

Scheme 3
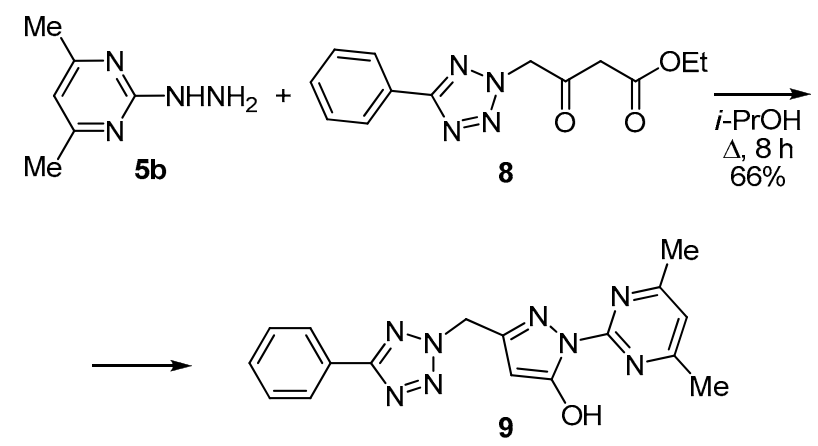

According to the results of X-ray structural analysis, compounds $\mathbf{7 b}$ and 9 are nonplanar systems. The torsion angle $\mathrm{HN}(5) \mathrm{N}(4) \mathrm{H}$ of the hydrazine fragment is $110^{\circ}$. The nitrogen atom in the pyrimidine ring has a trigonal pyramid configuration. The phenyl substituent lies practically in the same plane as the azole fragment, while the planes of the heterocycles intersect at a significant $\left(81^{\circ}\right)$ angle to each other. The peculiarities of molecular packing in the solid state are determined by the presence of intermolecular hydrogen bonds with the participation of protons of the hydrazine fragment. A feature of the structure of compound 9 is its existence in the 5-hydroxypyrazole form, rather than that of 2,3-dihydropyrazol-3-one. In this case, the conformation of the compound turned out to be locked by

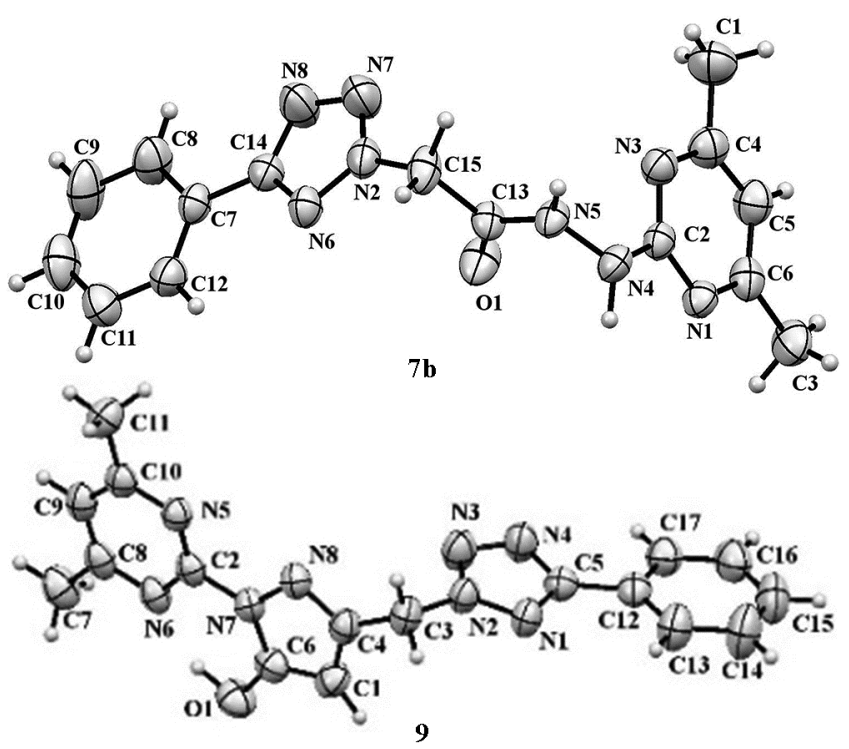

Figure 2. The molecular structures of compound $7 \mathbf{b}$ and $\mathbf{9}$ with atoms represented as thermal vibration ellipsoids of $50 \%$ probability. the intramolecular hydrogen bond $\mathrm{O}(1)-\mathrm{H}(1) \cdots \mathrm{N}(6)$ with the distance $\mathrm{O}(1) \cdots \mathrm{N}(6) 2.599 \AA$. At the same time, the tetrazole and pyrazole fragments of the molecule at the tetrahedral carbon atom are turned in relation to each other at an angle of $88.4^{\circ}$ which makes the conformation of this compound propeller-like. A solid-state structural feature is the packing of molecules in the form of stacks along the $0 \mathrm{a}$ axis in such a way that the pyrimidine fragments of neighboring molecules form interatomic $\pi-\pi$ contacts at a distance that is $0.05 \AA$ less than the sum of the van der Waals radii of the atoms of these fragments.

2-[(1-Phenyl-1 $H$-tetrazol-5-yl)sulfanyl]pyrimidine (12a) was obtained by hetarylation of 1-phenyl-5-sulfanyltetrazole (10a) with 2-chloropyrimidine (11). Likewise, \{5-[(4,6-dimethylpyrimidin-2-yl)sulfanyl]-1H-tetrazol-1-yl $\}$ acetic acid (12b) was synthesized from 1-carboxymethyl5-sulfanyltetrazole (10b) and 2-chloro-4,6-dimethylpyrimidine (2) (Scheme 4).

Scheme 4

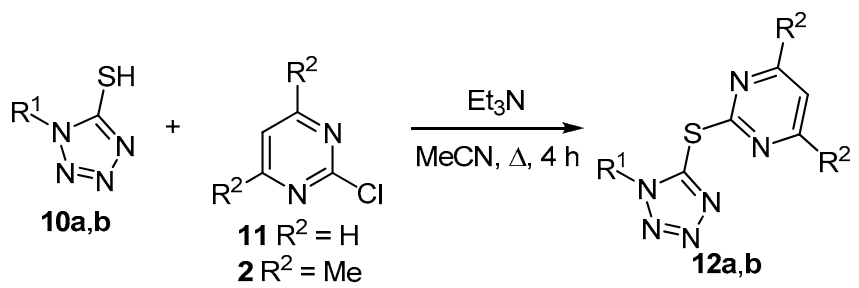

12 a $R^{1}=P h, R^{2}=H(46 \%)$, b $^{1}=\mathrm{CH}_{2} \mathrm{CO}_{2} \mathrm{H}, \mathrm{R}^{2}=\mathrm{Me}(66 \%)$

The prediction of the activity of nonannulated tetrazolylpyrimidines $\mathbf{7 a}, \mathbf{b}, \mathbf{9}$, and $\mathbf{1 2 a}, \mathbf{b}$, performed using the PASS computer system, ${ }^{11}$ indicates low ( $\left.\mathrm{Pa} 0.28-0.33\right)$ probability of antiviral activity for the compounds of this sample. However, low values of $P a$ factor are not always a verdict since they may indirectly indicate the novelty of the evaluated object. ${ }^{12}$ In this study, we investigated the in vitro antiviral activity of nonannulated tetrazolylpyrimidines 7a,b, 9, and 12a,b in the Laboratory of Experimental Virology of Saint Petersburg Pasteur Research Institute of Epidemiology and Microbiology. The study was carried out using the MDCK cell culture (ATCC CCL-34) against influenza virus strain A/Puerto Rico/8/34 (H1N1). Table 1 shows the values of $50 \%$ cytotoxic concentration $\left(\mathrm{CC}_{50}\right), 50 \%$ inhibitory concentration $\left(\mathrm{IC}_{50}\right)$, and selectivity index SI (the ratio of $\mathrm{CC}_{50}$ to $\mathrm{IC}_{50}$ ). Rimantadine was used as the reference drug. Compounds with a selectivity index of 10 and higher were considered promising.

The data in Table 1 illustrate that compounds $\mathbf{7 a}, \mathbf{b}, \mathbf{9}$, and 12a did not show activity against influenza virus strain A/Puerto Rico/8/34 (H1N1). The best results were obtained for compound $\mathbf{1 2 b}$, the SI of which is twice that of the reference drug (rimantadine), but, in contrast to it, compound 12b has significantly lower cytotoxicity. This result indirectly indicates the promise of further study of compounds of this group and an expanded search for substances with pronounced antiviral activity among nonannulated tetrazolylpyrimidines the heterocyclic fragments 
Table 1. Antiviral properties of nonannulated tetrazolylpyrimidines $\mathbf{7 a}, \mathbf{b}, \mathbf{9}$, and $\mathbf{1 2} \mathbf{a}, \mathbf{b}$ against influenza A H1N1 virus in MDCK cell cultures

\begin{tabular}{cccc}
\hline Compound & $\mathrm{CC}_{50}, \mu \mathrm{g} / \mathrm{ml}$ & $\mathrm{IC}_{50}, \mu \mathrm{g} / \mathrm{ml}$ & $\mathrm{SI}$ \\
\hline $\mathbf{7 a}$ & $>300$ & $>300$ & 1 \\
$\mathbf{7 b}$ & $>300$ & $>300$ & 1 \\
$\mathbf{9}$ & 53.9 & $>30$ & 2 \\
$\mathbf{1 2 a}$ & $>300$ & 170 & 2 \\
$\mathbf{1 2 b}$ & $>300$ & 31 & 10 \\
Rimantadine & 60 & 12 & 5 \\
\hline
\end{tabular}

of which are separated by a sulfur atom. The synthesis and study of the antiviral activity of analogs of compound 12b containing various functional groups at the nitrogen atom in position 1 of the tetrazole ring deserve further development. Importantly, the influenza virus used in the study is resistant to rimantadine (SI 5). The results of the study of tetrazolylpyrimidine $\mathbf{1 2 b}$ indicate that this compound may have a different mechanism of interaction with the target as compared to adamantane derivatives. This makes the evaluated group of compounds promising as prototypes of anti-influenza drugs with an alternative mechanism of action in comparison with existing drugs for influenza therapy.

To conclude, nonannulated tetrazolylpyrimidines can be recommended for in vivo evaluation of antiviral activity.

\section{Experimental}

IR spectra were registered on a Shimadzu 8400-FTIR spectrometer in $\mathrm{KBr}$ pellets. ${ }^{1} \mathrm{H}$ and ${ }^{13} \mathrm{C}$ NMR spectra were acquired on a Bruker Avance III spectrometer (400 and $100 \mathrm{MHz}$, respectively) in DMSO- $d_{6}$ (compounds 5a,b, 6 , 7a,b, 8, 9, 12a,b) and $\mathrm{CDCl}_{3}$ (compound 4) at $25^{\circ} \mathrm{C}$ with TMS as internal standard. Elemental analysis was performed on a Leco CHNS-932 elemental analyzer. Mass spectra were recorded on a Bruker maXis impact ultra-high resolution quadrupole time-of-flight mass spectrometer (electrospray ionization, $\mathrm{MeOH}$ solvent). Melting points were determined by the capillary method on a Büchi M-560 apparatus with a heating rate of $1{ }^{\circ} \mathrm{C} / \mathrm{min}$ in the melting range. Assessment of the purity of synthesized compounds was done by TLC on Macherey-Nagel Alugram Xtra SIL G plates, visualization in UV light $(254 \mathrm{~nm})$.

The physiochemical properties of 1-phenyl-5-sulfanyltetrazole (10a) and other commercial reagents, solvents, and materials correspond to the data given in the catalogs of Sigma-Aldrich, Merck, Fluka. 5-Phenyltetrazole sodium salt (1) ${ }^{13}$ 2-chloro-4,6-dimethylpyrimidine (2), ${ }^{14}$ 1-carboxymethyl-5-sulfanyltetrazole $(\mathbf{1 0 b}),{ }^{15}$ and 2-chloropyrimidine (11) ${ }^{16}$ were obtained following known or modified methods. The properties of compounds $\mathbf{1}, \mathbf{2}, \mathbf{1 0 b}$, and 11 correspond to those described previously. ${ }^{13-16}$

5,7-Dimethyl-3-phenyl[1,2,4] triazolo[4,3-a]pyrimidine (4). 2-Chloro-4,6-dimethylpyrimidine (2) $(0.86 \mathrm{~g}, 6.0 \mathrm{mmol})$ was added with stirring to a suspension of 5-phenyltetrazole sodium salt (1) $(1.0 \mathrm{~g}, 6.0 \mathrm{mmol})$ in DMSO $(20 \mathrm{ml})$. The reaction mixture was heated to $150^{\circ} \mathrm{C}$ and kept at this temperature for $8 \mathrm{~h}$. The mixture was then cooled, the formed precipitate was filtered off and dried in a stream of air. Yield $0.81 \mathrm{~g}(61 \%)$, colorless crystals, $\mathrm{mp} 259^{\circ} \mathrm{C}$ (decomp., PhMe-EtOH, 1:1) (decomp. temp. $\left.258^{\circ} \mathrm{C}(\mathrm{PhMe}-\mathrm{EtOH}, 1: 1)^{9}\right) . R_{\mathrm{f}} 0.47\left(\mathrm{CCl}_{4}-i-\mathrm{PrOH}, 4: 1\right.$, $\left.25^{\circ} \mathrm{C}\right)$. IR spectrum, $v, \mathrm{~cm}^{-1}: 3048(\mathrm{C}-\mathrm{H}), 1630\left(\mathrm{C}_{6} \mathrm{H}_{5}\right)$, $1518\left(\mathrm{C}_{4} \mathrm{~N}_{2} \mathrm{H}\right), \quad 1448\left(\mathrm{CN}_{4}\right), 764\left(\mathrm{C}_{4} \mathrm{~N}_{2} \mathrm{H}\right) .{ }^{1} \mathrm{H} \quad \mathrm{NMR}$ spectrum, $\delta$, ppm: $2.17\left(3 \mathrm{H}, \mathrm{s}, 5-\mathrm{CH}_{3}\right) ; 2.56\left(3 \mathrm{H}, \mathrm{s}, 7-\mathrm{CH}_{3}\right)$; $6.83(1 \mathrm{H}, \mathrm{s}, \mathrm{H}$ pyrimidine $)$; $7.51-7.65(5 \mathrm{H}, \mathrm{m}, \mathrm{H} \mathrm{Ph})$. ${ }^{13} \mathrm{C}$ NMR spectrum, $\delta$, ppm: $19.9\left(\mathrm{C}-5 \mathrm{CH}_{3}\right) ; 24.8(\mathrm{C}-7$ $\left.\mathrm{CH}_{3}\right) ; 111.7(\mathrm{C}-6) ; 128.3(\mathrm{C} \mathrm{Ph}) ; 129.7(\mathrm{C} \mathrm{Ph}) ; 130.5$ (C Ph); 131.5 (C Ph); 144.9 (C-3); 145.8 (C-9); 154.8 (C-7); 164.6 (C-5). Found, $m / z$ : $225.1135[\mathrm{M}+\mathrm{H}]^{+}$. $\mathrm{C}_{13} \mathrm{H}_{13} \mathrm{~N}_{4}$. Calculated, $m / z$ : 225.1135. Found, \%: C 69.22; $\mathrm{H}$ 5.28; $\mathrm{N}$ 24.80. $\mathrm{C}_{13} \mathrm{H}_{12} \mathrm{~N}_{4}$. Calculated, \%: C 69.62; H 5.39; N 24.98 .

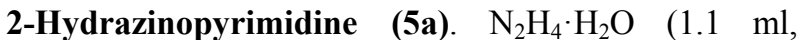
$14.0 \mathrm{mmol}$ ) was added with stirring at $10^{\circ} \mathrm{C}$ to a solution of 2-chloropyrimidine (11) (3.6 g, $25 \mathrm{mmol})$ in $\mathrm{EtOH}$ (15 ml). The precipitate that formed after a few hours was filtered off and dried in a stream of air. Yield $1.23 \mathrm{~g}(80 \%)$, colorless crystals, mp $112-113^{\circ} \mathrm{C}\left(\mathrm{EtOH}-\mathrm{H}_{2} \mathrm{O}, 1: 1\right)$ $\left(\begin{array}{lllll}(\mathrm{mp} & \left.112-113^{\circ} \mathrm{C} \quad\left(\mathrm{EtOH}-\mathrm{H}_{2} \mathrm{O}, \quad 1: 1\right)^{17}\right) . \quad R_{\mathrm{f}} & 0.11\end{array}\right.$ $\left(\mathrm{CCl}_{4}-i-\mathrm{PrOH}, 4: 1,25^{\circ} \mathrm{C}\right)$. IR spectrum, $v, \mathrm{~cm}^{-1}: 3255$ (N-H val), 1602, 1577, $798 \quad\left(\mathrm{C}_{4} \mathrm{~N}_{2} \mathrm{H}\right.$ def). ${ }^{1} \mathrm{H}$ NMR spectrum, $\delta$, ppm: $3.52(1 \mathrm{H}$, br. s, NH); 6.58-6.60 $(1 \mathrm{H}, \mathrm{m}$, $\mathrm{H}$ Ar); 6.97 (2H, br. s, $\left.\mathrm{NH}_{2}\right) ; 8.27-8.29(2 \mathrm{H}, \mathrm{m}, \mathrm{H} \mathrm{Ar})$. ${ }^{13} \mathrm{C}$ NMR spectrum, $\delta$, ppm: 110.9 (C-5); 158.3 (C-2); $164.8(\mathrm{C}-4,6)$. Found, $m / z$ : $111.0665[\mathrm{M}+\mathrm{H}]^{+} . \mathrm{C}_{4} \mathrm{H}_{7} \mathrm{~N}_{4}$. Calculated, $m / z$ : 111.0665. Found, \%: C 44.28; H 5.12; N 51.02. $\mathrm{C}_{4} \mathrm{H}_{6} \mathrm{~N}_{4}$. Calculated, \%: C 44.63; H 5.49; N 50.88 .

2-Hydrazino-4,6-dimethylpyrimidine (5b). $\mathrm{N}_{2} \mathrm{H}_{4} \cdot \mathrm{H}_{2} \mathrm{O}$ $(6 \mathrm{ml}, 124 \mathrm{mmol})$ was added with stirring at $10^{\circ} \mathrm{C}$ to a solution of 2-chloro-4,6-dimethylpyrimidine (2) (3.6 g, $25 \mathrm{mmol})$ in EtOH $(40 \mathrm{ml})$. The precipitate that formed after a few hours was filtered off and dried in a stream of air. Yield $2.4 \mathrm{~g}(70 \%)$, colorless crystals, $\mathrm{mp} 164-165^{\circ} \mathrm{C}$ $\left(\right.$ EtOH- $\left.\mathrm{H}_{2} \mathrm{O}, 1: 1\right)\left(\mathrm{mp} 165^{\circ} \mathrm{C}\left(\mathrm{EtOH}-\mathrm{H}_{2} \mathrm{O}, 1: 1\right)^{18}\right) . R_{\mathrm{f}} 0.54$ $\left(\mathrm{CCl}_{4}-i-\mathrm{PrOH}, 4: 1,25^{\circ} \mathrm{C}\right)$. IR spectrum, $v, \mathrm{~cm}^{-1}: 3307(\mathrm{~N}-\mathrm{H}$, val), $1371\left(\mathrm{C}-\mathrm{CH}_{3}\right), 1596,1467,794\left(\mathrm{C}_{4} \mathrm{~N}_{2} \mathrm{H}\right.$ def $)$. ${ }^{1} \mathrm{H}$ NMR spectrum, $\delta$, ppm: $2.22\left(6 \mathrm{H}, \mathrm{s}, 2 \mathrm{CH}_{3}\right) ; 3.36(1 \mathrm{H}$, br. s, NH); $6.38\left(1 \mathrm{H}, \mathrm{s}, \mathrm{H}\right.$ Ar); $7.88\left(2 \mathrm{H}\right.$, br. s, $\left.\mathrm{NH}_{2}\right)$. ${ }^{13} \mathrm{C}$ NMR spectrum, $\delta$, ppm: $23.9\left(2 \mathrm{CH}_{3}\right) ; 109.7(\mathrm{C}-5)$; 164.8 (C-2); 167.2 (C-4,6). Found, \%: C 52.33; H 7.80; $\mathrm{N}$ 40.54. $\mathrm{C}_{6} \mathrm{H}_{10} \mathrm{~N}_{4}$. Calculated, \%: C 52.16; H 7.30; $\mathrm{N} 40.55$.

2-(5-Phenyltetrazol-2-yl)acetic acid chloride (6). Crushed $\mathrm{PCl}_{5}(6.75 \mathrm{~g}, 32 \mathrm{mmol})$ was added to crushed 2-(5-phenyltetrazol-2-yl)acetic acid $(6.0 \mathrm{~g}, 29 \mathrm{mmol})$. The reaction mixture was heated in a boiling water bath (reaction flask was closed by a distillation drip adapter with a calcium chloride tube) until the mixture was homogenized and gas evolution stopped. Upon completion of the reaction, boiling hexane $(75 \mathrm{ml})$ was added to the hot reaction mixture, and the contents of the flask was cooled to $10^{\circ} \mathrm{C}$. Acid chloride 6 was filtered off, washed on a filter with chilled hexane, dried for $1 \mathrm{~h}$ under reduced pressure over $\mathrm{P}_{2} \mathrm{O}_{5}$ in a pistol dryer heated with $\mathrm{CHCl}_{3}$ vapor. Yield $6.43 \mathrm{~g}(96 \%)$, colorless crystals, $\mathrm{mp} 103-104^{\circ} \mathrm{C}$ (mp $103-$ 
$104^{\circ} \mathrm{C}$ (hexane) $\left.{ }^{19}\right)$. IR spectrum, $v, \mathrm{~cm}^{-1}: 2985,2945(\mathrm{C}-\mathrm{H})$, $1777(\mathrm{C}=\mathrm{O}), 1450,1278,1148,1073,1039,1022,923$ $\left(\mathrm{CN}_{4}\right), 729,688\left(\mathrm{C}_{6} \mathrm{H}_{5}\right) .{ }^{1} \mathrm{H}$ NMR spectrum, $\delta$, ppm: 5.84 $\left(2 \mathrm{H}, \mathrm{s}, \mathrm{CH}_{2}\right) ; 7.53-7.49(3 \mathrm{H}, \mathrm{m}, \mathrm{H} \mathrm{Ph}) ; 8.17-8.14(2 \mathrm{H}, \mathrm{m}$, $\mathrm{H} \mathrm{Ph}) .{ }^{13} \mathrm{C}$ NMR spectrum, $\delta$, ppm: $60.7\left(\mathrm{CH}_{2}\right) ; 126.6$ $(\mathrm{C} \mathrm{Ph}) ; 127.2(\mathrm{C} \mathrm{Ph}) ; 129.2$ (C Ph); $131.0(\mathrm{C} \mathrm{Ph}) ; 166.2$ (C tetrazole); $166.5(\mathrm{C}=\mathrm{O})$. Found, \%: C 48.31; H 3.20; N 25.60. $\mathrm{C}_{9} \mathrm{H}_{7} \mathrm{ClN}_{4} \mathrm{O}$. Calculated, \%: C 48.55; H 3.17; N 25.17.

$N^{\prime}$-(Pyrimidin-2-yl)-2-(5-phenyl-2H-tetrazol-2-yl)acetohydrazide (7a), a mixture of isomers $E / Z$ in a 3.6:1 ratio. $\mathrm{Et}_{3} \mathrm{~N}(0.97 \mathrm{~g}, 9.60 \mathrm{mmol})$ was added with stirring to a solution of 2-hydrazinopyrimidine (5a) $(1.0 \mathrm{~g}, 9.08 \mathrm{mmol})$ in $\mathrm{MeCN}(20 \mathrm{ml})$. The reaction mixture was cooled to $0-5^{\circ} \mathrm{C}$, and 2-(5-phenyltetrazol-2-yl)acetic acid chloride (6) $(2.0 \mathrm{~g}, 8.98 \mathrm{mmol})$ was added with stirring. The reaction mixture was heated under reflux for $4 \mathrm{~h}$. At the end heating, the solvent was removed under reduced pressure. The residue was washed with distilled $\mathrm{H}_{2} \mathrm{O}(2 \times 20 \mathrm{ml})$ and dried in a stream of air. Yield $1.3 \mathrm{~g}(48 \%)$, colorless crystals, mp $235-236^{\circ} \mathrm{C}\left(\mathrm{DMF}-\mathrm{H}_{2} \mathrm{O}, 1: 1\right) . R_{\mathrm{f}} 0.52\left(\mathrm{CCl}_{4}-\right.$ $i$-PrOH, $4: 1,25^{\circ} \mathrm{C}$ ). IR spectrum, $v, \mathrm{~cm}^{-1}: 3278$ (NH val), 3033 (C-H val), 1689 (C=O val), 1448, $1043\left(\mathrm{CN}_{4}\right), 819$, $788\left(\mathrm{C}_{4} \mathrm{~N}_{2} \mathrm{H}\right.$ def $) .{ }^{1} \mathrm{H}$ NMR spectrum, $\delta$, ppm: $5.64 *(2 \mathrm{H}, \mathrm{s}$, $\left.\mathrm{CH}_{2}\right) ; 5.66^{* *}\left(2 \mathrm{H}, \mathrm{s}, \mathrm{CH}_{2}\right) ; \quad 6.80-6.82^{* *}(1 \mathrm{H}, \mathrm{m}$, $\mathrm{H}$ pyrimidine $) ; 6.95-6.97^{*}(1 \mathrm{H}, \mathrm{H}$ pyrimidine $) ; 7.55-$ 7.60** (5H, m, H Ar); 8.02-8.09* (5H, m, H Ar); 8.408.42** (2H, m, H Ar); 8.53-8.54* (2H, m, H Ph); 9.17** $\left(1 \mathrm{H}, \mathrm{s}, \mathrm{NHC}_{4} \mathrm{~N}_{2} \mathrm{H}_{4}\right) ; 9.32 *\left(1 \mathrm{H}, \mathrm{s}, \mathrm{NHC}_{4} \mathrm{~N}_{2} \mathrm{H}_{4}\right) ; 9.84 *(1 \mathrm{H}$, $\mathrm{s}, \quad \mathrm{NHC}(\mathrm{O})) ; 10.45^{* *}(1 \mathrm{H}, \mathrm{s}, \quad \mathrm{NHC}(\mathrm{O})) .{ }^{13} \mathrm{C}$ NMR spectrum, $\delta$, ppm: 53.9* $\left(\mathrm{CH}_{2}\right) ; 54.1^{* *}\left(\mathrm{CH}_{2}\right) ; 113.3^{* *}$ (C-5 pyrimidine); 114.4* (C-5 pyrimidine); $126.8(\mathrm{C} \mathrm{Ph})$; 127.2 (C Ph); 129.8 (C Ph); 131.1 (C Ph);158.6 (C-2 pyrimidine $) ; 163.0^{* *}(\mathrm{C}=\mathrm{O}) ; 163.2^{*}(\mathrm{C}=\mathrm{O}) ; 164.6^{* *}$ (C-4,6 pyrimidine); $164.7^{*}$ (C-4,6 pyrimidine); 169.4 (C tetrazole). Found, $m / z$ : $297.1219[\mathrm{M}+\mathrm{H}]^{+} . \mathrm{C}_{13} \mathrm{H}_{13} \mathrm{~N}_{8} \mathrm{O}$. Calculated, $\mathrm{m} / \mathrm{z}$ : 297.1207. Found, \%: C 52.77; H 4.12; $\mathrm{N}$ 37.49. $\mathrm{C}_{13} \mathrm{H}_{12} \mathrm{~N}_{8} \mathrm{O}$. Calculated, \%: C 52.70; H 4.08; N 37.82 .

$N^{\prime}$-(4,6-Dimethylpyrimidin-2-yl)-2-(5-phenyl-2H-tetrazol-2-yl)acetohydrazide (7b), a mixture of isomers $E / Z$ in a 2.9:1 ratio. $\mathrm{Et}_{3} \mathrm{~N}(0.44 \mathrm{~g}, 4.31 \mathrm{mmol})$ and 2-hydrazino4,6-dimethylpyrimidine (5b) (0.6 g, $4.35 \mathrm{mmol})$ were added with stirring to a solution of 2-(5-phenyltetrazol2-yl)acetic acid chloride (6) (0.96 g, $4.31 \mathrm{mmol})$ in $\mathrm{MeCN}$ $(20 \mathrm{ml})$. The reaction mixture was heated under reflux for $4 \mathrm{~h}$. The mixture was concentrated to half the original volume by evaporation under reduced pressure. The remaining mixture was cooled, the formed precipitate was filtered off, washed on a filter with distilled $\mathrm{H}_{2} \mathrm{O}(2 \times 20 \mathrm{ml})$, and dried in a stream of air. Yield $1.1 \mathrm{~g}(78 \%)$, colorless crystals, mp $228^{\circ} \mathrm{C}\left(\mathrm{DMF}-\mathrm{H}_{2} \mathrm{O}, 1: 1\right)$. $R_{\mathrm{f}} 0.54\left(\mathrm{CCl}_{4}-\right.$ $i$-PrOH, $\left.4: 1,25^{\circ} \mathrm{C}\right)$. IR spectrum, $v, \mathrm{~cm}^{-1}: 3307(\mathrm{~N}-\mathrm{H}$ val), 3033 (C-H val), 1683 (C=O val), 1450, $1041\left(\mathrm{CN}_{4}\right), 819$, $788\left(\mathrm{C}_{4} \mathrm{~N}_{2} \mathrm{H}\right.$ def $) .{ }^{1} \mathrm{H}$ NMR spectrum, $\delta$, ppm: $2.26^{* *}(6 \mathrm{H}$, $\left.\mathrm{s}, 2 \mathrm{CH}_{3}\right) ; 2.33 *\left(6 \mathrm{H}, \mathrm{s}, 2 \mathrm{CH}_{3}\right) ; 5.61 *\left(2 \mathrm{H}, \mathrm{s}, \mathrm{CH}_{2}\right) ; 5.62 * *$

* Hereinafter in the Experimental, one asterisk $(*)$ denotes the signals of the $Z$-isomer, two asterisks ( $\left.{ }^{* *}\right)$ denote the signals of the $E$-isomer. $\left(2 \mathrm{H}, \mathrm{s}, \mathrm{CH}_{2}\right) ; 6.57^{* *}(1 \mathrm{H}, \mathrm{s}, \mathrm{H}$ pyrimidine $) ; 6.71^{*}(1 \mathrm{H}, \mathrm{s}$, $\mathrm{H}$ pyrimidine); 7.57-7.60 (3H, m, H Ph); 8.06-8.09 (2H, $\mathrm{m}, \mathrm{H} \mathrm{Ph}) ; 8.90^{* *}\left(1 \mathrm{H}, \mathrm{s}, \mathrm{NHC}_{4} \mathrm{~N}_{2} \mathrm{H}_{4}\right) ; 9.09^{*}(1 \mathrm{H}, \mathrm{s}$, $\left.\mathrm{NHC}_{4} \mathrm{~N}_{2} \mathrm{H}_{4}\right) ; 9.79 *(1 \mathrm{H}, \mathrm{s}, \mathrm{NHC}(\mathrm{O})) ; 10.40 * *(1 \mathrm{H}, \mathrm{s}, \mathrm{NHC}$ $(\mathrm{O})) .{ }^{13} \mathrm{C}$ NMR spectrum, $\delta$, ppm: $23.9 * *\left(2 \mathrm{CH}_{3}\right) ; 24.0^{*}$ $\left(2 \mathrm{CH}_{3}\right) ; 53.9^{*}\left(\mathrm{CH}_{2}\right) ; 54.1^{* *}\left(\mathrm{CH}_{2}\right) ; 111.9^{* *}(\mathrm{C}-5$ pyrimidine); 112.9* (C-5 pyrimidine); $126.8(\mathrm{C} \mathrm{Ph}) ; 127.3$ (C Ph); 129.8 (C Ph); $131.1 \quad(\mathrm{C} \quad \mathrm{Ph}) ; 162.9 \quad(\mathrm{C}-2$ pyrimidine); $164.5^{* *}(\mathrm{C}=\mathrm{O}) ; 164.7(\mathrm{C}$ tetrazole $) ; 167.6^{* *}$ (C-4,6 pyrimidine); 168.1 (C-4,6 pyrimidine); 169.2* $(\mathrm{C}=\mathrm{O})$. Found, $m / z: 325.1530 \quad[\mathrm{M}+\mathrm{H}]^{+} . \quad \mathrm{C}_{15} \mathrm{H}_{17} \mathrm{~N}_{8} \mathrm{O}$. Calculated, $m / z$ : 325.1520. Found, \%: C 55.43; H 4.82; $\mathrm{N}$ 34.25. $\mathrm{C}_{15} \mathrm{H}_{16} \mathrm{~N}_{8} \mathrm{O}$. Calculated, \%: C 55.55; H 4.97; N 34.55 .

Ethyl 3-oxo-4-(5-phenyl-2H-tetrazol-2-yl)butanoate (8). Ethyl 4-chloro-3-oxobutanoate $(10.0 \mathrm{~g}, 61 \mathrm{mmol})$ and benzyltriethylammonium chloride $(0.01 \mathrm{~g}, 0.044 \mathrm{mmol})$ were added with stirring at $80^{\circ} \mathrm{C}$ to a suspension of 5-phenyltetrazole sodium salt (1) $(10.2 \mathrm{~g}, 61 \mathrm{mmol})$ in $\mathrm{MeCN}(150 \mathrm{ml})$. The reaction mixture was stirred at $80^{\circ} \mathrm{C}$ for $3 \mathrm{~h}$ and cooled to room temperature. The formed precipitate was filtered off and dried in a stream of air. Yield $10.65 \mathrm{~g}(56 \%)$, beige crystals, $\mathrm{mp} 75-76^{\circ} \mathrm{C}(\mathrm{PhMe}-$ $\mathrm{EtOH}, 1: 1) . R_{\mathrm{f}} 0.8\left(\mathrm{CCl}_{4}-i-\mathrm{PrOH}, 4: 1,25^{\circ} \mathrm{C}\right)$. IR spectrum, $v, \mathrm{~cm}^{-1}: 1715,1749(\mathrm{C}=\mathrm{O}), 1530\left(\mathrm{C}_{6} \mathrm{H}_{5}\right), 1452,1044$ $\left(\mathrm{CN}_{4}\right) .{ }^{1} \mathrm{H}$ NMR spectrum, $\delta$, ppm $(J, \mathrm{~Hz}): 1.22(3 \mathrm{H}, \mathrm{t}$, $\left.J=6.9, \mathrm{CH}_{3}\right) ; 3.92\left(2 \mathrm{H}, \mathrm{s}, 2-\mathrm{CH}_{2}\right) ; 4.15(2 \mathrm{H}, \mathrm{q}, J=6.9$, $\left.\mathrm{CH}_{2}\right) ; 6.10\left(2 \mathrm{H}, \mathrm{s}, 4-\mathrm{CH}_{2}\right) ; 7.56-7.59(2 \mathrm{H}, \mathrm{m}, \mathrm{H} \mathrm{Ph}) ; 8.06-$ $8.10(3 \mathrm{H}, \mathrm{m}, \mathrm{H} \mathrm{Ph}) \cdot{ }^{13} \mathrm{C}$ NMR spectrum, $\delta, \mathrm{ppm}: 14.4$ $\left(\mathrm{CH}_{3}\right) ; 46.6(\mathrm{C}-2) ; 61.2\left(\mathrm{CH}_{2}\right) ; 61.3(\mathrm{C}-4) ; 126.8(\mathrm{C} \mathrm{Ph})$; 127.1 (C Ph); 129.8(C Ph); 131.1 (C Ph); 164.7 $(C$ tetrazole); $166.8(\mathrm{C}(1)=\mathrm{O}) ; 195.9(\mathrm{C}(3)=\mathrm{O})$. Found, $m / z$ : $297.0958[\mathrm{M}+\mathrm{Na}]^{+} . \quad \mathrm{C}_{13} \mathrm{H}_{14} \mathrm{~N}_{4} \mathrm{NaO}_{3}$. Calculated, $m / z$ : 297.0958. Found, \%: C 56.89; H 5.01; N 20.27. $\mathrm{C}_{13} \mathrm{H}_{14} \mathrm{~N}_{4} \mathrm{O}_{3}$. Calculated, \%: C 56.93; H 5.15; N 20.43.

1-(4,6-Dimethylpyrimidin-2-yl)-3-[(5-phenyl-2Htetrazol-2-yl)methyl]-1H-pyrazol-5-ol (9). Ethyl 3-oxo4-(5-phenyl-2H-tetrazol-2-yl)butanoate (8) (1.16 g, $4.23 \mathrm{mmol}$ ) was added to a solution of 2-hydrazino4,6-dimethylpyrimidine (5b) $(0.58 \mathrm{~g}, 4.23 \mathrm{mmol})$ in $i$-PrOH $(50 \mathrm{ml})$. The reaction mixture was heated under reflux for $8 \mathrm{~h}$. The mixture was concentrated to half the original volume by evaporation under reduced pressure, the remaining mixture was cooled to room temperature, and $10 \%$ aqueous $\mathrm{NaOH}(20 \mathrm{ml})$ was added. The formed precipitate was filtered off, the filtrate was acidified with $\mathrm{HCl}$ to $\mathrm{pH} 2-3$. The formed precipitate was filtered off and dried in a stream of air. Yield $0.97 \mathrm{~g}(66 \%)$, beige crystals, mp $175-176^{\circ} \mathrm{C}(\mathrm{PhMe}) . R_{\mathrm{f}} 0.58\left(\mathrm{CCl}_{4}-i-\mathrm{PrOH}, 4: 1,25^{\circ} \mathrm{C}\right)$. IR spectrum, $v, \mathrm{~cm}^{-1}$ : 1448, $1040\left(\mathrm{CN}_{4}\right), 784\left(\mathrm{C}_{4} \mathrm{~N}_{2} \mathrm{H}\right.$ def $)$. ${ }^{1} \mathrm{H}$ NMR spectrum, $\delta$, ppm: $2.50\left(6 \mathrm{H}, \mathrm{s}, 2 \mathrm{CH}_{3}\right) ; 5.71(1 \mathrm{H}$, s, H Ar); $5.93\left(2 \mathrm{H}, \mathrm{s}, \mathrm{CH}_{2}\right) ; 7.28(1 \mathrm{H}, \mathrm{s}, \mathrm{H} \mathrm{Ar}) ; 7.56-7.58$ $(3 \mathrm{H}, \mathrm{m}, \mathrm{H} \mathrm{Ph}) ; 8.06-8.08(2 \mathrm{H}, \mathrm{m}, \mathrm{H} \mathrm{Ph}) ; 12.27(1 \mathrm{H}, \mathrm{s}$, $\mathrm{OH}) .{ }^{13} \mathrm{C}$ NMR spectrum, $\delta$, ppm: $23.8\left(2 \mathrm{CH}_{3}\right) ; 51.8\left(\mathrm{CH}_{2}\right)$; 87.0 (C-4 pyrazole); 118.2 (C-5 pyrimidine); $126.8(\mathrm{C} \mathrm{Ph})$, $127.3(\mathrm{C} \mathrm{Ph}) ; 129.8(\mathrm{C} \mathrm{Ph}) ; 131.1(\mathrm{C} \mathrm{Ph}) ; 147.4(\mathrm{C}-3$ pyrazole); 156.6 (C-2 pyrimidine); 158.1 (C-5 pyrazole); 164.7 (C tetrazole); 168.8 (C-4,6 pyrimidine). Found, $m / z$ : $349.1527[\mathrm{M}+\mathrm{H}]^{+} . \mathrm{C}_{17} \mathrm{H}_{17} \mathrm{~N}_{8} \mathrm{O}$. Calculated, $m / z$ : 349.1520 . 
Found, \%: C 58.35; H 4.71; N 32.36. $\mathrm{C}_{17} \mathrm{H}_{16} \mathrm{~N}_{8} \mathrm{O}$. Calculated, \%: C 58.61; H 4.63; N 32.17.

2-[(1-Phenyl-1 $H$-tetrazol-5-yl)sulfanyl]pyrimidine (12a). $\mathrm{Et}_{3} \mathrm{~N}(0.85 \mathrm{~g}, 8.42 \mathrm{mmol})$ and 2-chloropyrimidine (11) $(1.1 \mathrm{~g}, 9.60 \mathrm{mmol})$ were added with stirring to a solution of 1-phenyl-1 $H$-tetrazole-5-thiol (10a) $(1.5 \mathrm{~g}, 8.42 \mathrm{mmol})$ in $\mathrm{MeCN}(10 \mathrm{ml})$. The reaction mixture was heated under reflux for $4 \mathrm{~h}$. The mixture was concentrated to half the original volume by evaporation under reduced pressure, the remaining reaction mixture was cooled, and $\mathrm{H}_{2} \mathrm{O}(50 \mathrm{ml})$ was added. The formed precipitate was filtered off and dried in a stream of air. Yield $1.0 \mathrm{~g}(46 \%)$, beige crystals, $\mathrm{mp} 76^{\circ} \mathrm{C}(\mathrm{PhMe}-\mathrm{EtOH}, 1: 1) . R_{\mathrm{f}} 0.17\left(\mathrm{CCl}_{4}-i-\mathrm{PrOH}, 4: 1\right.$, $\left.25^{\circ} \mathrm{C}\right)$. IR spectrum, $v, \mathrm{~cm}^{-1}: 1554\left(\mathrm{C}_{6} \mathrm{H}_{5}\right), 1444,1045$ $\left(\mathrm{CN}_{4}\right), 765\left(\mathrm{C}_{4} \mathrm{~N}_{2} \mathrm{H}\right.$ def $) .{ }^{1} \mathrm{H}$ NMR spectrum, $\delta$, ppm: 7.30 $7.32(1 \mathrm{H}, \mathrm{m}, \mathrm{H}$ pyrimidine); 7.56-7.57 (3H, $\mathrm{m}, \mathrm{H} \mathrm{Ph}) ; 7.69-$ $7.71(2 \mathrm{H}, \mathrm{m}, \mathrm{H}$ pyrimidine $)$; $8.58-8.59(2 \mathrm{H}, \mathrm{m}, \mathrm{H} \mathrm{Ph})$. ${ }^{13} \mathrm{C}$ NMR spectrum, $\delta$, ppm: $119.8(\mathrm{C}-5) ; 125.7(\mathrm{C} \mathrm{Ph})$; 130.0 (C Ph); 131.2 (C Ph); 133.9 (C Ph); 148.3 (C-4,6); 159.3 (C-2); 167.1 (C tetrazole). Found, $\mathrm{m} / \mathrm{z}: 257.0616$ $[\mathrm{M}+\mathrm{H}]^{+} . \mathrm{C}_{11} \mathrm{H}_{9} \mathrm{~N}_{6} \mathrm{~S}$. Calculated, $m / z$ : 257.0604. Found, \%: C 51.59; H 3.28; N 32.44; $\mathrm{S} 12.62 . \mathrm{C}_{11} \mathrm{H}_{8} \mathrm{~N}_{6} \mathrm{~S}$. Calculated, $\%$ : C 51.55; H 3.15; N 32.79; S 12.51 .

\{5-[(4,6-Dimethylpyrimidin-2-yl)sulfanyl]-1 $H$-tetrazol1-yl\}acetic acid (12b). $\mathrm{Et}_{3} \mathrm{~N}(1.27 \mathrm{~g}, 12.57 \mathrm{mmol})$ and chloro-4,6-dimethylpyrimidine (2) $(0.89 \mathrm{~g}, 6.24 \mathrm{mmol})$ were added with stirring to a solution of 2-(5-sulfanyl- $1 \mathrm{H}$ tetrazol-1-yl)acetic acid (10b) $(1.0 \mathrm{~g}, 6.25 \mathrm{mmol})$ in $\mathrm{MeCN}$ $(25 \mathrm{ml})$. The reaction mixture was heated under reflux with stirring for $4 \mathrm{~h}$. The solvent was removed under reduced pressure. The oily residue was dissolved in $\mathrm{H}_{2} \mathrm{O}(20 \mathrm{ml})$. The resulting solution was acidified with $\mathrm{HCl}$ to $\mathrm{pH} 2-3$ and extracted with EtOAc $(3 \times 20 \mathrm{ml})$. The combined extracts were washed with $\mathrm{H}_{2} \mathrm{O}$ and dried over $\mathrm{MgSO}_{4}$. EtOAc was removed under reduced pressure. Yield $1.1 \mathrm{~g}$ $(66 \%)$, beige crystals, $\mathrm{mp} 92^{\circ} \mathrm{C}(\mathrm{PhMe}) . R_{\mathrm{f}} 0.2\left(\mathrm{CCl}_{4}-\right.$ $i$-PrOH 4:1, 25 $\left.{ }^{\circ} \mathrm{C}\right)$. IR spectrum, $v, \mathrm{~cm}^{-1}: 2995(\mathrm{O}-\mathrm{H})$, $1743\left(\mathrm{CH}_{2}-\mathrm{COOH}\right), 1423,1037\left(\mathrm{CN}_{4} \mathrm{val}\right), 883\left(\mathrm{C}_{4} \mathrm{~N}_{2} \mathrm{H}\right.$ def). ${ }^{1} \mathrm{H}$ NMR spectrum, $\delta$, ppm: $2.31\left(6 \mathrm{H}, \mathrm{s}, 2 \mathrm{CH}_{3}\right) ; 5.38$ $\left(2 \mathrm{H}, \mathrm{s}, \mathrm{CH}_{2}\right) ; 7.15(1 \mathrm{H}, \mathrm{s}, \mathrm{H}$ pyrimidine $) ; 13.72(1 \mathrm{H}$, br. s, $\mathrm{OH}) .{ }^{13} \mathrm{C}$ NMR spectrum, $\delta$, ppm: $23.7\left(2 \mathrm{CH}_{3}\right) ; 49.2\left(\mathrm{CH}_{2}\right)$; 118.8 (C-5); 148.5 (C-2); 165.3 (C tetrazole); 167.5 $(\mathrm{C}-4,6) ; 169.1(\mathrm{C}=\mathrm{O})$. Found, $\mathrm{m} / \mathrm{z}: 267.0681[\mathrm{M}+\mathrm{H}]^{+}$. $\mathrm{C}_{9} \mathrm{H}_{11} \mathrm{~N}_{6} \mathrm{O}_{2} \mathrm{~S}$. Calculated, $m / z$ : 267.0659. Found, \%: C $40.97 ; \mathrm{H} 4.03 ; \mathrm{N} 31.35 ; \mathrm{S}$ 12.05. $\mathrm{C}_{9} \mathrm{H}_{10} \mathrm{~N}_{6} \mathrm{O}_{2} \mathrm{~S}$. Calculated, \%: C 40.60; H 3.79; N 31.56; S 12.04 .

The study of the biological activity of compounds 7a,b, 9, 12a,b. A series of threefold dilutions (300$3.7 \mu \mathrm{g} / \mathrm{ml}$ ) were prepared from the studied compounds. The dilutions were introduced into the wells of plates with a monolayer of MDCK cells. The plates were incubated for $72 \mathrm{~h}$ at $36^{\circ} \mathrm{C}$ in $5 \% \mathrm{CO}_{2}$. The analysis of cell survival was carried out using the methyl tetrazolium (MTT) assay: MTT solution was added to the wells, wherein by the action of mitochondrial enzymes it transforms into an insoluble violet formazan derivative. ${ }^{20}$ The plates with cells were kept at $36^{\circ} \mathrm{C}$ in an atmosphere of $5 \% \mathrm{CO}_{2}$ for $2 \mathrm{~h}$. The precipitate was dissolved in DMSO $(0.1 \mathrm{ml}$ per well). The optical density in the wells was measured on a Thermo
Multiskan FC photometer (Thermo Fisher Scientific, USA) at a wavelength of $540 \mathrm{~nm}$. Based on the obtained data, the $\mathrm{CC}_{50}$ value was calculated, that is, the concentration of the compound leading to a decrease in optical density by half compared to the wells without addition of compounds.

The study of the antiviral activity of compounds $7 a, b$, 9, 12a,b was carried by determining the reduction of the degree of cytopathic effect. The experiments used influenza virus strains A/Puerto Rico/8/34 (H1N1) and B/Florida/4/2006. The studied compounds in various concentrations were added to the cells in the wells of the plate, incubated for $1 \mathrm{~h}$ at $36^{\circ} \mathrm{C}$ in $5 \% \mathrm{CO}_{2}$, then the cells were infected with the virus at a dose of $0.01 \mathrm{TCID}_{50}$ per cell. The cells were incubated for $72 \mathrm{~h}$ at $36^{\circ} \mathrm{C}$ in $5 \% \mathrm{CO}_{2}$, after which the cell viability assay was performed using the methyl tetrazolium assay as described above. Based on the obtained data, a $50 \%$ inhibitory concentration was calculated for each compound, that is, the concentration that reduces the degree of viral cell destruction by $50 \%$.

$\mathrm{X}$-ray structural analysis of compounds $7 \mathrm{~b}$ and 9 was carried out on an Xcalibur 3 automatic 4-circle diffractometer equipped with a CCD detector. All calculations were carried out in the Olex software shell using the SHELX software package. ${ }^{21}$ The full set of X-ray structural data for compounds $\mathbf{7 b}$ and $\mathbf{9}$ was deposited at the Cambridge Crystallographic Data Center (deposits CCDC 1818619 and CCDC 2047135, respectively).

This work was supported by the Russian Foundation for Basic Research (projects 20-53-00039-Bel_a and 20-5305010 Arm_a, 20RF-138).

$X$-ray structural analysis for compounds $7 \boldsymbol{b}$ and $\mathbf{9}$ was carried out on the equipment of the Center for Collective Use "Spectroscopy and Analysis of Organic Compounds" of Postovsky Institute of Organic Synthesis of the Ural Branch of the Russian Academy of Sciences.

\section{References}

1. Kiselev, O. I. Khimiopreparaty $i$ khimioterapiya grippa (Chemo Drugs and Influenza Chemotherapy [In Russian]); Saint Petersburg: Rostok, 2011, p. 9.

2. Rusinov, V. L.; Charushin, V. N.; Chupakhin, O. N. Russ. Chem. Bull., Int. Ed. 2018, 67, 573. [Izv. Akad. Nauk, Ser. Khim. 2018, 573.]

3. Sabitov, A. U.; Belousov, V. V.; Edin, A. S.; Oleinichenko, E. V.; Gladunova, E. P.; Tikhonova, E. P.; Kuzmina, T. Yu.; Kalinina, Yu. S.; Sorokin, P. V. Antibiotiki i khimioterapiya 2020, 65(7-8), 27.

4. Popova, E. A.; Trifonov, R. E.; Ostrovskii, V. A. Russ. Chem. Rev. 2019, 88, 644. [Usp. Khim. 2019, 88, 644.]

5. Rewcastle, G. W. Comprehensive Heterocyclic Chemistry III; Elsevier: Oxford, 2008, Vol. 8, p. 120.

6. (a) Egorova, A. P.; Makarov, V. A. Russ. Chem. Bull., Int. Ed. 2020, 69, 635. [Izv. Akad. Nauk, Ser. Khim. 2020, 635.] (b) Zarubaev, V. V.; Golod, E. L.; Anfimov, P. M.; Shtro, A. A.; Saraev, V. V.; Gavrilov, A. S.; Logvinov, A. V.; Kiselev, O. I. Bioorg. Med. Chem. 2010, 18, 839.

7. Pochinok, V. Ya.; Avramenko L. F.; Grigorenko, P. S.; Skopenko, V. N. Russ. Chem. Rev. 1975, 44, 481. [Usp. Khim. 1975, 44, 1028.] 
8. Scapin, E.; Salbego, P. R. S.; Bender, C. R.; Meyer, A. R.; Pagliari, A. B.; Orlando, T.; Zimmer, G. C.; Frizzo, C. P.; Bonacorso, H. G.; Zanatta, N.; Martins, M. A. P. Beilstein J. Org. Chem. 2017, 13, 2396.

9. Bower, J. D.; Doyle, F. P. J. Chem. Soc. 1957, 727.

10. Ostrovskii, V. A.; Popova, E. A.; Trifonov R. E. $A d v$. Heterocycl. Chem. 2017, 123, 1.

11. Poroikov, V. V. Biomed. Chem. 2020, 14, 3, 216. [Biomeditsinskaya Khimiya 2020, 66, 30].

12. Filimonov, D. A.; Druzhilovskiy, D. S.; Lagunin, A. A.; Gloriozova, T. A.; Rudik, A. V.; Dmitriev, A. V.; Pogodin, P. V.; Poroikov, V. V. Biomedical Chemistry: Research and Methods 2018, 1(1), 1.

13. Tsentovskii, V. M.; Bashkirtseva, V. E.; Evgen'ev, M. I.; Ivanova, Z. P.; Poplavskii, V. S.; Ostrovskii, V. A.;
Koldobskii, G. I. Chem. Heterocycl. Compd. 1983, 19, 1238. [Khim. Geterotsikl. Soedin. 1983, 1556.]

14. Kosolapoff, G. M.; Roy, C. H. J. Org. Chem. 1961, 26, 1895.

15. DeSelms, R. Ch.; Kapecki, J. A. EP Patent 0299725.

16. Singh, J. N.; Lal, A. B. J. Indian Chem. Soc. 1966, 43, 308.

17. Brown, D. J.; Ford, P. W. J. Chem Soc. C 1967, 568.

18. Brady, L. E.; Herbst, R. M. J. Org. Chem. 1959, 24, 922.

19. Putis, S. M.; Zubarev, V. Yu.; Poplavskii, V. S.; Ostrovskii, V. A. Chem. Heterocycl. Compd. 2004, 40, 854. [Khim. Geterotsikl. Soedin. 2004, 997.]

20. Mosmann, T. J. Immunol. Methods 1983, 16, 55.

21. Dolomanov, O. V.; Bourhis, L. J.; Gildea, R. J.; Howard, J. A. K.; Puschmann, H. J. Appl. Crystallogr. 2009, 42, 339. 